\title{
PENGEMBANGAN MEDIA PEMBELAJARAN INTERAKTIF BERBASIS ANDROID PADA MATA PELAJARAN IPA POKOK BAHASAN PERKEMBANGBIAKAN HEWAN UNTUK SISWA KELAS VI SD
}

\author{
H. P.S. Muttaqin ${ }^{1}$, Sariyasa ${ }^{2}$, N. K. Suarni ${ }^{3}$ \\ ${ }^{123}$ Program Studi Pendidikan Dasar \\ Universitas Pendidikan Ganesha \\ Singaraja, Indonesia \\ e-mail: prastisnojati@undiksha.ac.id ${ }^{1}$, sariyasa@undiksha.ac.id ${ }^{2}$, \\ niketut.suarni@undiksha.ac.id ${ }^{3}$
}

\begin{abstract}
Abstrak
Penelitian ini bertujuan untuk memperoleh media pembelajaran interaktif berbasis android yang valid dan praktis pada mata pelajaran IPA pokok bahasan perkembangbiakan hewan kelas VI SD. Penelitian ini merupakan penelitian pengembangan dengan menggunakan model ADDIE (Analyse, Design, Development, Implementation, Evaluation) yang terdiri dari tahap: 1) analisis, (2) desain, (3) pengembangan, (4) implementasi, dan (5) evaluasi. Tahap implementasi tidak dilaksanakan dalam penelitian ini. Subjek penelitian ini adalah ahli materi dan ahli media, guru, serta murid kelas VI SD. Metode pengumpulan data yang digunakan adalah kuesioner dengan memberikan lembar penilaian kepada 2 orang dosen sebagai ahli materi dan ahli media, 3 orang guru sebagai praktisi (pengguna), serta 10 orang murid pada uji coba kelompok kecil yang bertujuan untuk memperoleh data tingkat validitas dan kepraktisan media hasil pengembangan. Instrumen yang digunakan untuk mengukur tingkat validitas dan kepraktisan media pembelajaran interaktif berbasis android adalah skala nilai berupa lembar penilaian media pembelajaran oleh ahli materi, ahli media, dan murid. Data yang diperoleh kemudian dianalisis dengan menggunakan rumus mean untuk mengetahui rerata skor validitas dan kepraktisan media pembelajaran hasil pengembangan. Hasil analisis data terhadap media pembelajaran interaktif berbasis android diperoleh skor validasi oleh ahli materi dengan rerata skor sebesar 4,8 dari skor maksimum 5 dengan kategori "Sangat Baik", kemudian ahli media diperoleh rerata skor sebesar 4,8 dari skor maksimum 5 dengan kategori "Sangat Baik". Selanjutnya skor pada uji coba kelompok kecil diperoleh rerata skor sebesar 4,5 dari skor maksimum 5 yang berada pada kategori "Sangat Baik". Dengan demikian hasil validasi dari ahli materi, ahli media, dan uji coba kelompok kecil menyatakan bahwa produk pengembangan media pembelajaran berbasis android valid dan praktis. Hasil penelitian ini memberi wawasan kepada program studi Pendidikan Dasar bahwa penggunaan teknologi yang mengikuti perkembangan zaman, akan berdampak positif dalam bidang pendidikan.
\end{abstract}

Kata kunci: Android; Media Pembelajaran Interaktif; Perkembangbiakan Hewan

\begin{abstract}
The aim of this research was to obtain a valid and practical android-based interactive learning media for science subjects on animal reproduction for sixth grade elementary school students. This research was a development research which was carried out by using the ADDIE (Analyze, Design, Development, Implementation, Evaluation) model in five steps, namely: (1) analysis, (2) design, (3) development, (4) implementation, and (5) evaluation. The implementation step was not carried out in this research. The subject of this research are expert of subject content and instructional media, teacher, as well as a sixth grade elementary school student. The data collection method used was questionnaire method by providing assessment sheet to 2 lecturers as expert of subject content and instructional media and 3 teachers as the user (practitioner), and 10 students in a small-group trial which aims to obtain data
\end{abstract}


on the level of validity and practicality of the media. The instrument used to measure the level of validity and practicality of android-based interactive learning media was rating scale of media assessment sheet by the material experts, media experts, and students. The obtained data then analyzed by using a mean formula to determine the average score validity and practicality of learning media as a result of development. The results of data analysis on android-based interactive learning media obtained an average validation score by expert of subject content was 4.8 from a maximum score of 5 with "Very Good" category, then expert of instructional media obtained an average score of 4.8 from a maximum score of 5 with "Very Good" category. Furthermore, the score on the small-group trial obtained an average of 4.5 from a maximum score of 5 which is in the "Very Good" category. Thus the validation results from material experts, media experts, and small-scale trials state that the android-based learning media development product is valid and practical. The results of this study provide insight to the Education study program that the use of technology that follows the times will have a positive impact in the field of education.

Keywords : Android; Interactive Learning Media; Animal Reproduction

\section{PENDAHULUAN}

Era 4.0 industri ditandai dengan berkembangnya berbagai ilmu pengetahuan dan teknologi yang begitu pesat, ribuan konten digital dan berbagai jenis aplikasi multi platform membanjiri kehidupan manusia. Keadaan ini bahkan sudah menjadi suatu hal yang tidak asing lagi bagi sebagian besar masyarakat, dimana perkembangan teknologi telah memasuki berbagai lini kehidupan. Suryanti (2018) mengatakan bahwa dalam era revolusi 4.0 ini teknologi berkembang sangat cepat beriringan dengan kebutuhan manusia di berbagai bidang kehidupan.

Pesatnya perkembangan teknologi ini tentu menjadi tantangan bagi para guru agar mampu berperan dan memfasilitasi peserta didik dalam rangka membangun pengetahuan di era global. Sari, et al. (2021) menyebutkan bahwa pemanfaatan teknologi sudah tidak dapat dihindarkan lagi karena memang sudah zamannya, seorang guru dituntut agar dapat mengikuti perubahan dan perkembangan ini dengan tujuan mempersiapkan siswa menghadapi perubahan. Salah satu konsekuensi dari pesatnya perkembangan ilmu pengetahuan dan teknologi tersebut mengharuskan pembentukan sumber daya manusia yang berkualitas, yaitu sumber daya manusia yang memiliki kompetensi terhadap penguasaan ilmu pengetahuan dan teknologi serta mampu untuk mengimbangi dan memanfaatkan dengan baik. Untuk menghadapi era globalisasi, penguasaan teknologi menjadi sangat penting dimiliki oleh peserta didik sehingga mampu menghadapi globalisasi dan tidak ketinggalan jaman (Fauzi, 2020).

Seorang pendidik diharapkan mampu merencanakan pembelajaran yang menarik dan komunikatif sehingga dapat mewujudkan harapan pemerintah dalam mencerdaskan anak bangsa. Dalam upaya mencapai pembelajaran yang optimal, tidak hanya dipengaruhi oleh komunikasi yang efektif, akan tetapi juga dipengaruhi oleh media pembelajaran yang dipakai oleh pendidik untuk menyampaikan materi pembelajaran. Sebagaimana disebutkan oleh Yulia (2018) bahwa melalui media pembelajaran akan dapat mendorong peserta didik dalam mengikuti kegiatan pembelajaran, menjalankan posisinya, dan meningkatkan terjadinya efektifitas proses pembelajaran.

Kata "media" berdasarkan terminologinya berasal dari bahasa latin "medium" yang memiliki arti "perantara atau sarana penghubung" (Sumiharsono, et al.,2017). Selain didukung oleh penyampaian materi yang komunikatif oleh guru, penggunaan media yang menarik akan membuat peserta didik lebih antusias dalam pelaksanaan pembelajaran (Nurseto, 2019). Jadi dengan penggunaan media pembelajaran yang tepat sebagai alat bantu 
dalam menyampaikan informasi atau mengajar akan dapat meningkatkan motivasi belajar peserta didik.

Perkembangan teknologi yang begitu pesat perlu dimanfaatkan dengan baik dalam dunia pendidikan. Salah satu fenomena yang terjadi saat ini adalah begitu dekatnya produk teknologi dalam hal ini perangkat smartphone atau android dengan kehidupan dan keseharian peserta didik. Handayani dan Rahayu (2020) menyebutkan bahwa pelaksanaan pembelajaran dengan memanfaatkan multimedia pembelajaran interaktif android akan mampu menarik minat dan kesenangan murid, serta meningkatkan motivasi murid untuk belajar yang dapat disesuaikan dengan tingkat kecepatan pemahaman murid masing-masing.

Seorang guru dituntut untuk melakukan suatu inovasi dengan membuat media pembelajaran berbasis teknologi, sehingga dapat lebih menarik minat dan mempermudah siswa dalam belajar. Hal ini sejalan dengan yang diungkapkan oleh Ichsan, et al. (2018) yang mengatakan bahwa dengan berkembangnya teknologi di era yang serba modern ini maka membuat seorang guru harus melakukan inovasi terkait media pembelajaran yang akan digunakan dalam proses pembelajaran. Untuk menerapkan pembelajaran yang aktif, guru diharuskan menggunakan cara-cara yang efektif sehingga mampu meningkatkan kreativitas dan minat siswa, salah satu caranya adalah dengan menggunakan media pembelajaran yang aktif, inovatif, kreatif, efektif, menyenangkan, dan kekinian (Desriana, et al, 2018). Perangkat android, selain memiliki fungsi sebagai alat komunikasi, juga berpeluang untuk digunakan dalam mengembangkan media pembelajaran yang dapat dimanfaatkan oleh siswa. Pengintegrasian teknologi dalam pembelajaran merupakan salah satu solusi dalam mencapai tujuan pembelajaran, mengingat saat ini perangkat android sudah menjadi teman sehari-hari dikalangan peserta didik.
SD No. 6 Pecatu merupakan salah satu sekolah dasar negeri yang berada di wilayah Gugus VII kecamatan Kuta Selatan Kabupaten Badung. Secara umum dapat dikatakan bahwa siswa sudah terbiasa dalam memanfaatkan dan menggunakan perangkat android. Pendukung pernyataan ini adalah berdasarkan data kuesioner siswa kelas VI yang berjumlah 49 responden pada tahun ajaran 20202021 di SD Gugus VII Kecamatan Kuta Selatan pada tanggal 27 Januari-10 Februari 2021 yang menunjukkan bahwa (1) terdapat $83,7 \%$ siswa sudah memiliki perangkat smartphone sendiri dan sisanya adalah milik orang tua; (2) terdapat $85,7 \%$ siswa menyebutkan bahwa smartphone yang dimilikinya sudah bersistem android dan sisanya adalah besistem IOS; (3) siswa menyebutkan bahwa frekuensi penggunaan smartphone paling banyak digunakan untuk membuka whats app, game online, youtube, dan tik tok. Kemudian dari hasil wawancara tidak terstruktur terhadap beberapa siswa kelas VI diketahui bahwa mereka sudah terbiasa dalam memanfaatkan smartphonenya dalam mencari tugas maupun menemukan materi tambahan yang diberikan oleh guru ketika belajar di rumah. Berdasarkan paparan yang telah dijelaskan diatas diketahui bahwa sebagian besar siswa sudah memiliki perangkat smartphone sendiri dan sudah terbiasa dalam mengoperasikannya. Namun pemanfaatan dan penggunaan dalam kegiatan pembelajaran belum dilakukan secara optimal, karena smartphone yang mereka miliki lebih sering digunakan untuk bermain game, membuka whats app, menonton video di youtube, dan bermain tik tok. Hal ini sejalan dengan yang diungkapkan oleh Handoyono dan Mahmud (2020) yang mengungkapkan bahwa penggunaan smartphone bisa dikatakan kurang berjalan secara optimal, hal ini dikarenakan siswa hanya memanfaatkan smartphone untuk sarana hiburan seperti bermain game dan bermedia sosial. Seharusnya dengan begitu dekat dan familiarnya perangkat android 
dengan kehidupan sehari-hari siswa dapat dimanfaatkan dengan baik dalam menunjang kegiatan belajar. Semakin dekat dan familiarnya teknologi dalam bidang pendidikan, dalam hal ini perangkat android, belum dimanfaatkan dengan baik oleh guru dengan melakukan inovasi dan kreasi dalam menggunakan dan mengembangkan media pembelajaran yang valid dan sesuai dengan kebutuhan dan perkembangan zaman. Pendukung pernyataan ini adalah kuesioner yang ditujukan pada 20 guru di Gugus VII kecamatan Kuta Selatan pada tanggal 4 April 2021 terkait penggunaan dan pemanfaatan media. Pada kuesioner ini masing-masing guru diberikan pilihan untuk menentukan 3 jenis media yang paling sering digunakan pada mata pelajaran IPA, hasilnya menunjukkan bahwa yang berada pada urutan pertama adalah video pembelajaran dipilih oleh 20 guru, kemudian power point dan buku teks masing-masing dipilih oleh 16 guru, dan lingkungan sekitar dipilih oleh 4 guru, serta hanya 1 guru yang menyatakan pernah menggunakan aplikasi android dalam kegiatan belajar mengajar. Hasil studi dokumen terhadap silabus dan RPP IPA kelas VI pada Gugus VII kecamatan Kuta Selatan yang menunjukkan bahwa penggunaan media oleh guru masih sebatas power point dengan bantuan proyektor, cuplikan video pembelajaran, dan buku. Penggunaan buku pun masih sebatas pada buku paket yang telah disediakan oleh sekolah.

Penggunaan media pembelajaran berbasis teknologi yang belum optimal, berpengaruh terhadap pemahaman dan hasil belajar IPA siswa. Hal ini ditunjukkan pada nilai UAS siswa kelas VI di SD No. 6 Pecatu Kecamatan Kuta Selatan yang sebagian siswanya masih belum mencapai standar kriteria ketuntasan minimal. KKM yang ditetapkan pada mata pelajaran IPA adalah 75. Namun siswa yang belum tuntas hasil belajarnya adalah sebanyak 10 siswa dari 15 siswa. Ke-10 siswa tersebut masih memiliki nilai hasil belajar IPA dibawah 75 . Hasil tersebut memberi gambaran seberapa lemahnya tingkat pemahaman konsepkonsep IPA yang sebenarnya sudah diajarkan, yang berakibat pada tidak mampunya untuk mengaplikasikan, menerangkan keterhubungan antar konsep, dan memecahkan masalah dalam IPA. Salah satu penyebab lemahnya pemahaman konsep dan hasil belajar IPA disinyalir karena masih minimnya pemanfaatan media pembelajaran terutama yang berbasis teknologi sebagai alat penyampai pesan dalam pelaksanaan pembelajaran di sekolah-sekolah (Umi, 2016). Jika hal ini terus diabaikan, maka pemahaman konsep IPA siswa Indonesia akan semakin menurun dan terus tertinggal.

Diperlukan suatu terobosan dan inovasi untuk mengembangkan suatu media pembelajaran interaktif dengan berbasis android sehingga dapat meningkatkan pemahaman IPA dan pemanfaatan smartphone dalam proses pembelajaran. Penelitian tentang pengembangan media pembelajaran berbasis android pernah diteliti sebelumnya, salah satunya adalah yang dilakukan oleh Kuswanto (2019) menemukan bahwa penggunaan media pembelajaran dengan berbasis android layak digunakan sebagai media pembelajaran yang praktis, ekonomis, dan sesuai dengan fasilitas yang dimiliki siswa. Kendala yang ditemukan dalam penelitian ini adalah dibutuhkan android dengan spesifikasi yang tinggi dengan RAM 1 GB dan Memori internal 4 GB agar media pembelajaran dapat berjalan dengan lancar. Selanjutnya penelitian yang dilakukan oleh Nurwahyuningtyas (2017) menunjukkan bahwa penilaian dari ahli media dan ahli materi berada pada kategori sangat baik, dan memiliki tingkat keefektifan sangat baik yang dibuktikan dari rerata hasil pretest dan postest siswa. Kekurangan yang ditemukan pada penelitian ini adalah belum berisi konten animasi dan video pembelajaran. Pada penelitian yang peneliti lakukan media pembelajaran akan dibuat dengan mempertimbangkan spesifikasi smartphone terendah sehingga dengan RAM 500 MB 
dan memori intenal 1 GB sudah dapat menjalankan aplikasi. Selain itu, didalam aplikasi akan disisipkan animasi dan video berkaitan dengan materi perkembangbiakan hewan.

Berdasarkan beberapa masalah yang diungkapkan diatas dan beberapa solusi yang diberikan oleh peneliti mengenai aplikasi berbasis android yang terbukti berdampak positif, maka pada penelitian kali ini peneliti mengembangkan media pembelajaran interaktif berbasis android pada topik perkembangbiakan hewan dengan menggunakan SAC (smart app creator) dengan tujuan untuk menjawab tantangan global dengan lebih mengedepankan teknologi yang serba praktis dan menyenangkan. SAC adalah salah satu software yang dapat digunakan untuk membuat aplikasi berbasis ios dan android yang dapat dirancang tanpa kode pemrograman serta dapat juga dibuat dengan format HTML5 dan .exe. (Widiastika, et. al.:2021).

Terdapat tiga tujuan penelitian dalam penelitian pengembangan ini, yaitu untuk (1) mendeskripsikan bentuk media pembelajaran interaktif berbasis android menggunakan Smart App Creator (SAC) pada mata pelajaran IPA pokok bahasan perkembangbiakan hewan untuk siswa kelas VI SD; (2) mendeskripsikan hasil validitas media pembelajaran interaktif berbasis android menggunakan Smart App Creator pada mata pelajaran IPA pokok bahasan perkembangbiakan hewan untuk siswa kelas VI SD, (3) mendeskripsikan hasil uji kepraktisan media pembelajaran interaktif berbasis android menggunakan Smart App Creator pada mata pelajaran IPA pokok bahasan perkembangbiakan hewan untuk siswa kelas VI SD.

\section{METODE}

Penelitian dan pengembangan ini bertujuan untuk memperoleh sebuah produk media pembelajaran interaktif berbasis android pada mata pelajaran IPA untuk siswa kelas VI sekolah dasar. Pada penelitian pengembangan ini, yang menjadi subjek penelitian adalah para ahli materi dan media, serta 10 orang murid kelas VI SD No. 6 Pecatu Gugus VII Kecamatan Kuta Selatan. Sedangkan objek penelitiannya adalah tingkat validitas dan kepraktisan media pembelajaran interaktif berbasis android pada mata pelajaran IPA dengan topik perkembangbiakan hewan kelas VI SD.

Model yang digunakan dalam mengembangkan media pembelajaran ini adalah model ADDIE yang di populerkan oleh Raiser dan Mollenda. ADDIE adalah akronim dari Analysis-Design-DevelopImplement-Evaluate yang sekaligus merupakan tahap-tahap dalam prosedur penelitiannya. Model ADDIE ini mempunyai prosedur sistematis sehingga dapat menghasilkan produk yang valid, serta cocok untuk diterapkan pada produk yang akan dikembangkan (Tegeh, et al., 2014). Pada penelitian ini tahap implementasi tidak dilaksanakan. Hal ini dikarenakan adanya keterbatasan finansial, waktu, tenaga, dan sumber daya.

Tahap analisis dilakukan melalui tiga tahap yaitu analisis kebutuhan, analisis kurikulum, dan analisis karakteristik peserta didik. Mulyatiningsih (2014) menyebutkan bahwa hal yang mengawali adanya pengembangan metode/model maupun media pembelajaran adalah karena disebabkan terdapatnya masalah dalam media/metode/model yang telah diterapkan. Langkah awal yang dilakukan peneliti dalam penelitian pengembangan ini adalah dengan cara melakukan kegiatan studi dokumen, wawancara tidak tersrtuktur dan penyebaran angket/kuesioner terhadap guru dan siswa yang berada di lingkungan Gugus VII Kecamatan Kuta Selatan dengan tujuan untuk menentukan masalah yang dihadapi oleh sekolah dan kebutuhan apa yang sekiranya tepat terhadap permasalahan yang akan ditemukan.

Tahap desain merupakan tahap pembuatan rancangan (blue print). Diibaratkan sebuah gedung, maka tahap 
awal yang harus dilakukan sebelum dilaksanakan pembangunan adalah membuat sebuah rancang bangun (Perwita et.al:2019). Tahap ini diawali dengan pembuatan garis besar isi media (GBIM) yang merupakan kegiatan yang dilakukan untuk memadukan materi yang akan dimuat dikombinasikan dengan media-media yang diperlukan dalam menjelaskan konsep dalam media yang akan dikembangkan. Kegiatan selanjutnya adalah menyusun flowchart dan menyusun naskah. Naskah ini merupakan kerangka untuk keseluruhan peristiwa dan jalan cerita yang akan ditunjukkan dalam media dengan topik perkembangbiakan hewan.

Tahap pengembangan merupakan langkah lanjutan setelah tahap desain, hasil blue print yang telah dibuat diwujudkan menjadi nyata pada tahap ini (Perwita, et al., 2019). Dengan kata lain tahap ini merupakan kegiatan merealisasikan produk media pembelajaran interaktif berbasis android pada topik perkembangbiakan hewan yang dibuat dan dikemas dalam bentuk file .apk. Setelah pengembangan media pembelajaran selesai dilakukan, selanjutnya dilakukan uji coba produk dengan tujuan tingkat validitas dan kelayakan media hasil pengembangan.

Desain uji coba untuk mengetahui kelayakan dan validitas serta kepraktisan produk dalam penelitian ini dilaksanakan sampai uji ahli dan uji coba kelompok kecil yang dilaksanakan oleh dua orang dosen dan tiga orang guru serta sepuluh orang murid kelas VI. Setelah dilakukan validasi oleh ahli materi dan media pada uji ahli, kemudian hasilnya dianalisis sesuai dengan data yang diperoleh dan dilakukan revisi jika ada saran dan komentar dari ahli. Tahap selanjutnya adalah dilakukan uji coba kelompok kecil dengan melibatkan murid kelas VI.

Terdapat dua jenis data dalam penelitian ini, yaitu kuantitatif dan kualitatif. Data kualitatif didapat saat dilakukan review oleh para ahli dan praktisi serta siswa yang berupa komentar, saran dan masukan terkait media pembelajaran hasil pengembangan. Data kuantitatif didapat dengan menyerahkan angket kepada para ahli dan praktisi serta siswa yang hasil akhirnya dalam bentuk skor.

Kuesioner merupakan metode yang digunakan oleh peneliti dalam penelitian pengembangan ini. Instrumen penelitian ini menggunakan skala nilai (rating scale), yaitu melalui pemberian tanda check tertentu pada suatu data mentah yang berupa angka jika didapatkan gejala yang muncul dalam kolom daftar yang telah disediakan, kemudian diinterpretasikan ke dalam pengertian deskriptif. Terdapat dua buah instrumen yang akan divalidasi oleh ahli dalam kegiatan penelitian ini, yaitu angket validasi materi pembelajaran yang digunakan untuk mengetahui tingkat kevalidan materi yang terdapat dalam media hasil pengembangan, dan angket validasi media pembelajaran yang digunakan untuk mengetahui tingkat kevalidan media pembelajaran hasil pengembangan. Selain itu juga terdapat angket respon siswa yang digunakan untuk mengetahui tingkat kepraktisan media pembelajaran.

Sebelum dilakukan review oleh ahli dan murid, instrumen yang digunakan harus valid. Validitas isi instrumen perlu di uji melalui uji judges. Dalam peneltian ini uji validitas isi menggunakan rumus Gregory.

Berdasarkan uji validitas isi ketiga instrumen, menunjukkan bahwa koefisien validitas isi instrumen materi pembelajaran, validitas isi instrumen media pembelajaran, dan validitas isi instrumen uji coba kelompok kecil $=1$, sehingga validitas isi ketiga instrumen tersebut sangat tinggi.

Pada penelitian pengembangan ini, diperoleh dua jenis data yaitu data analisis deskriptif kualitatif dan data analisis deskriptif kuantitatif. Analisis deskriptif kualitatif merupakan suatu metode dengan melakukan proses deskripsi pada data yang telah diperoleh dari hasil penelitian. Analisa data deskriptif kualitatif didapatkan dari data hasil kuesioner yang telah diisi oleh ahli dan siswa pada uji coba kelompok kecil yang 
berisi kritik, saran, dan masukan yang kemudian diolah dan dianalisa secara deskriptif. Analisis deskriptif kuantitatif merupakan sebuah metode yang memiliki sifat induktif, ilmiah dan objektif terhadap data yang diperoleh dalam bentuk angka, nilai, atau skor yang kemudian dianalisis dalam analisis statistika (Hermawan, 2019). Data tersebut berupa skor yang diperoleh melalui lembar penilaian dari ahli dan siswa. Rata-rata skor yang didapat lalu dikonversi dengan berpedoman pada konversi skala lima seperti tabel.

Tabel 1. Penilaian Skala Lima

\begin{tabular}{ll}
\hline Rentang Skor & Kriteria \\
\hline $4,01<X \leq 5,01$ & Sangat Baik \\
$3,34<X \leq 4,01$ & Baik \\
$2,66<X \leq 3,34$ & Cukup \\
$1,99<X \leq 2,66$ & Tidak Baik \\
$0,99<X \leq 1,99$ & Sangat Tidak Baik \\
\hline & Sumber: Koyan (2012)
\end{tabular}

\section{HASIL DAN PEMBAHASAN}

Produk yang dikembangkan merupakan inti dalam pelaksanaan penelitian pengembangan ini. Penelitian pengembangan ini bertujuan untuk memperoleh sebuah produk media pembelajaran interaktif berbasis android pada mata pelajaran IPA pokok bahasan perkembangbiakan hewan yang ditujukan pada siswa kelas VI SD.

Kegiatan analisis kebutuhan dilaksanakan menggunakan kuesioner, studi dokumen dan wawancara. Hasil analisis diketahui bahwa sebagian besar siswa sudah memiliki perangkat smartphone sendiri dan sudah terbiasa dalam mengoperasikannya. Namun pemanfaatan dan penggunaan dalam kegiatan pembelajaran belum dilakukan secara optimal, karena smartphone yang mereka miliki lebih sering digunakan untuk bermain game, membuka whats app, menonton video di youtube, dan bermain tik tok. Demikian juga dengan guru, dimana guru belum optimal dalam memanfaatkan dan mengembangkan media berbasis teknologi sesuai dengan kebutuhan dan tuntutan zaman. Kegiatan analisis kurikulum dikaji $\mathrm{KD}$ yang terdapat di kelas $\mathrm{VI}$, kemudian dirumuskan menjadi IPK dari KD tersebut. Dibutuhkan hardware pembangun berupa laptop atau komputer dengan spesifikasi RAM 2 GB dan memori internal $1 \mathrm{~GB}$ sehingga dapat menjalankan software SAC dengan baik dan lancar.

Pada tahap design dilakukan peracangan produk. Kegiatan perancangan ini diawali dengan pembuatan Garis Besar Isi Media, kemudian dilanjutkan tahap penyusunan jabaran materi, membuat flowchart, dan menyusun naskah. Pada flowchart ini ditunjukkan tentang topik perkembangbiakan hewan, pembabakan materi dari topik perkembangbiakan hewan, dan jalur yang bisa diikuti setelah pemakai program (user) memberikan respon. Kemudian dalam naskah dimuat tentang desain tombol, desain tulisan, desain latar belakang aplikasi, dan desain tampilan menu.

Tahap development merupakan tahap merealisasikan produk media pembelajaran interaktif berbasis android yang dibuat dan dikemas dalam bentuk file .apk. Media pembelajaran ini dibuat dalam format stand alone (berdiri sendiri) yang dapat diinstal dan dijalan secara offline (tanpa koneksi internet) pada smartphone bersistem android. Pengembangan media pembelajaran interaktif ini dibuat dengan menggunakan software smart app creator (SAC) yang disusun berdasarkan flowchart dan desain interface yang telah disusun pada tahap sebelumnya. Berikut disajikan tampilan aplikasi smart app creator seperti pada Gambar 1. 


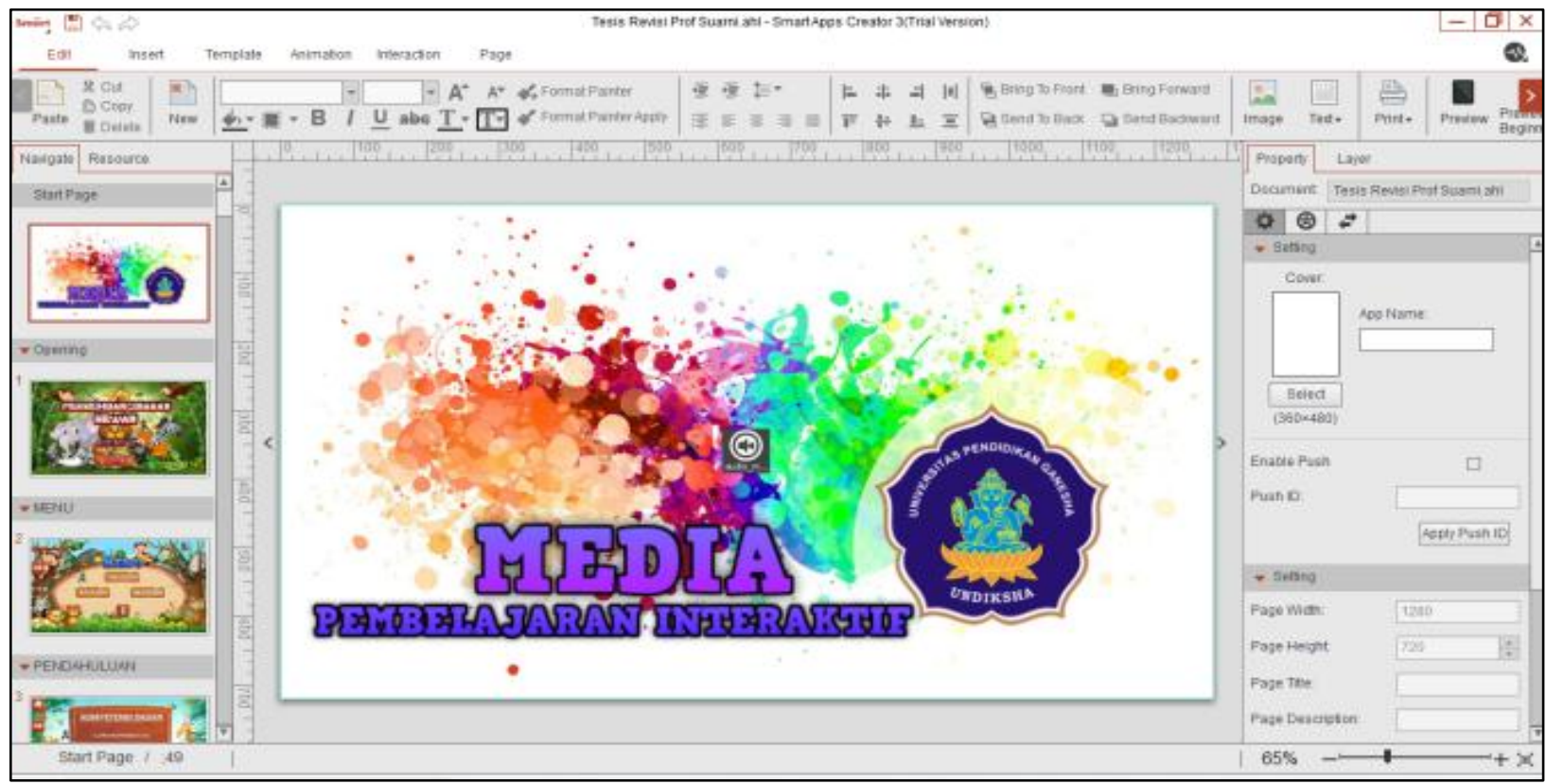

Gambar 1. Tampilan Aplikasi SAC

Aplikasi media pembelajaran interaktif ini mengelaborasikan berbagai jenis gambar, animasi hewan, video pembelajaran hewan, audio narasi materi dan bacsound. Aplikasi ini dapat dijalankan menggunakan aplikasi android secara stand alone (offline) dengan rincian sebagai berikut: (1) Jenis Media: Multimedia; (2) Ukuran download: 77,67 MB; (3) Versi:2.0, (4) OS: Minimal 4.4 KitKat.

Materi yang terkandung dalam media pembelajaran interaktif ini mencakup jenis perkembangbiakan hewan secara vegetatif dan generatif. Media pembelajaran ini dilengkapi dengan game mencocokkan gambar dan kata serta terdapat pula latihan soal berbentuk pilihan ganda berjumlah 20 soal. Selain itu, terdapat pula video penjelasan mengenai materi perkembangbiakan vegetatif dan perkembangbiakan generatif pada hewan. Tampilan media pembelajaran interaktif berbasis android hasil pengembangan dapat dilihat pada Gambar 2 dibawah.

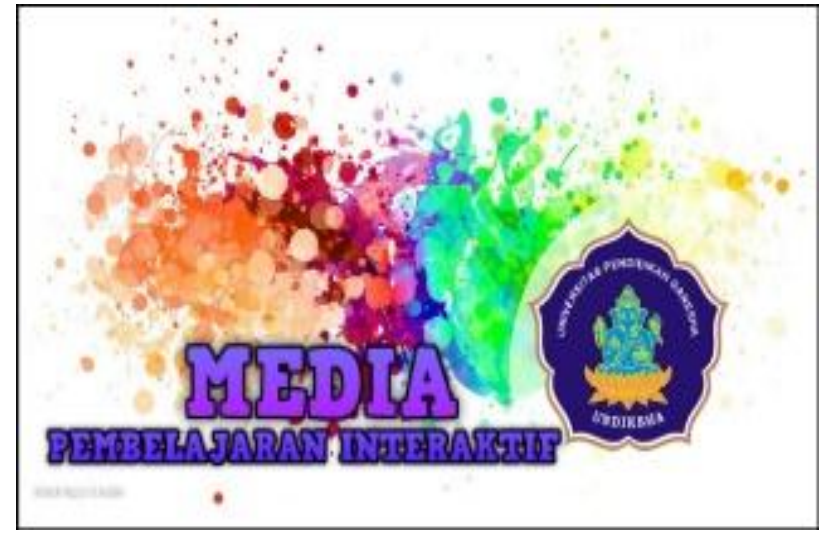

Start Page

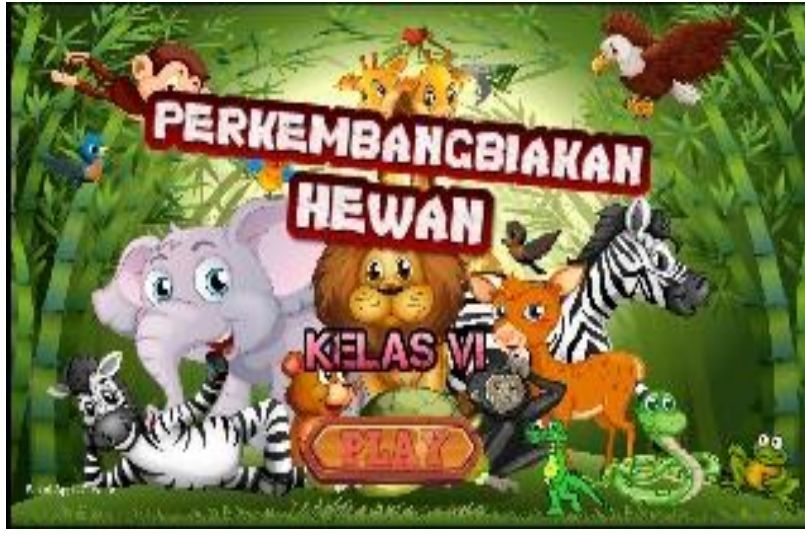

Opening 


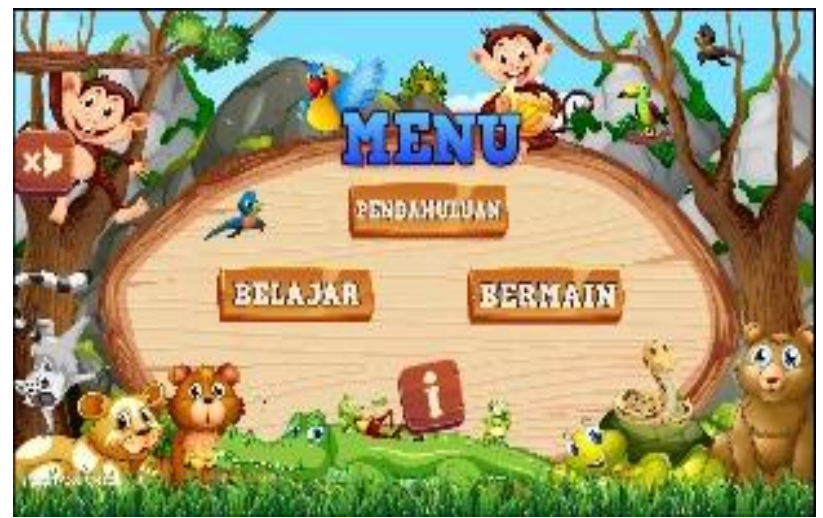

Menu

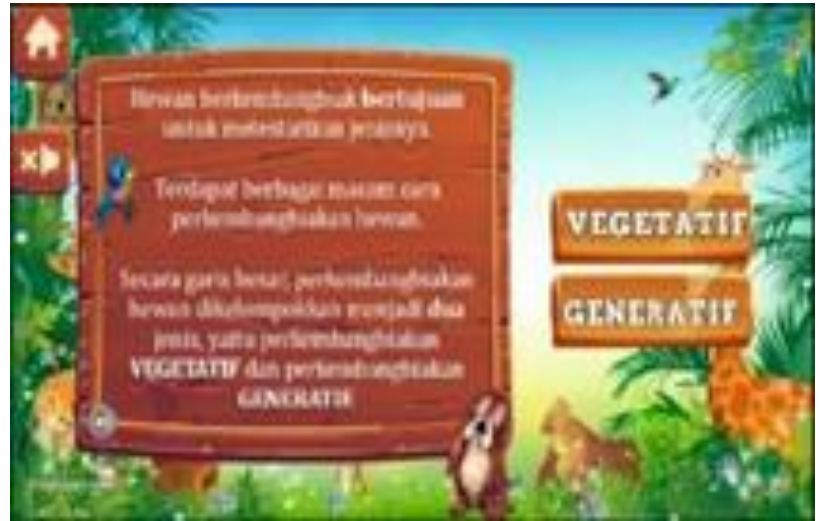

Belajar

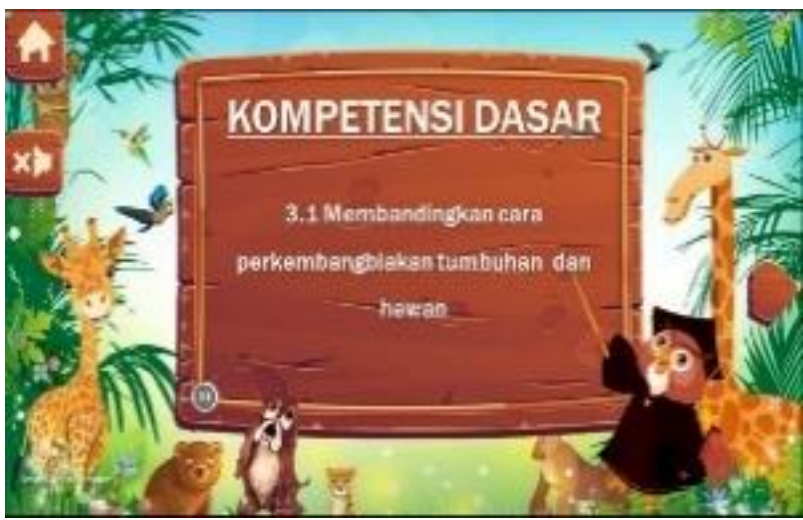

Pendahuluan

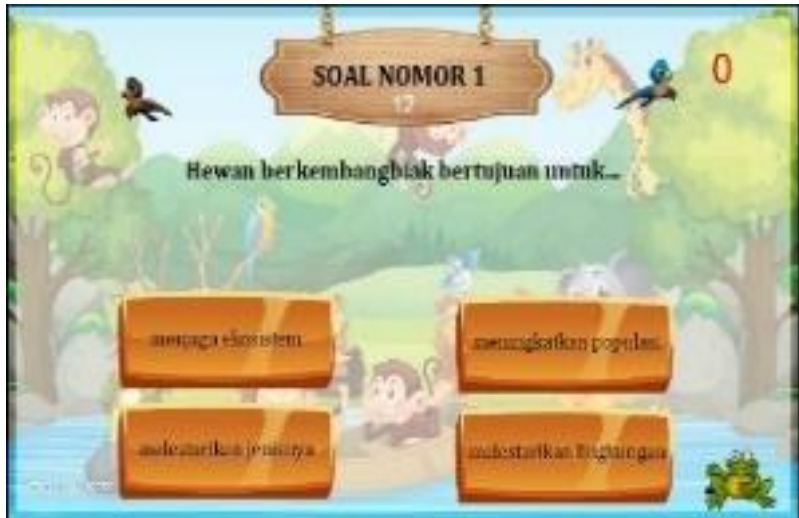

Pemain

Gambar 2. Tampilan Media Pembelajaran

Berdasarkan data penilaian dari proses validasi ahli materi, media, dan uji coba kelompok kecil diperoleh data secara keseluruhan penilaian hasil pengembangan media interaktif berbasis android. Data keseluruhan penilaian media pembelajaran interaktif adalah seperti pada Gambar 3 dan Tabel 2.

Tabel 2. Data Hasil Penilaian Media Pembelajaran Interaktif Aspek

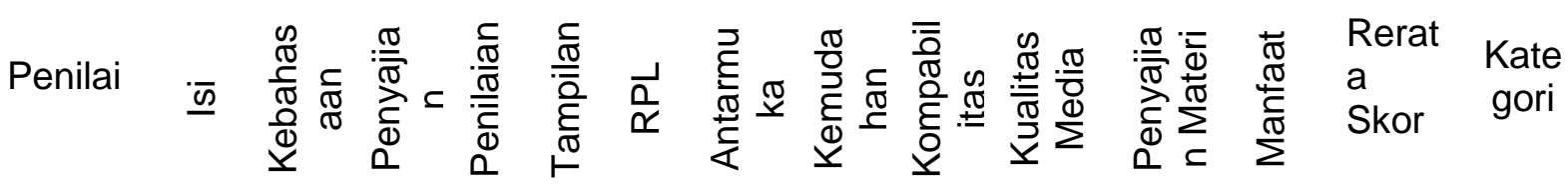

\begin{tabular}{|c|c|c|c|c|c|c|c|c|c|c|c|c|c|c|}
\hline $\begin{array}{l}\text { Validasi } \\
\text { Ahli } \\
\text { Materi }\end{array}$ & $\begin{array}{l}4 \\
7\end{array}$ & 4,8 & 4,8 & $\begin{array}{l}4 \\
9\end{array}$ & - & - & - & - & - & - & - & - & 4,8 & $\begin{array}{l}\text { San } \\
\text { gat } \\
\text { Baik }\end{array}$ \\
\hline $\begin{array}{l}\text { Validasi } \\
\text { Ahli } \\
\text { Media }\end{array}$ & - & - & - & - & $\begin{array}{l}4 \\
7\end{array}$ & $\begin{array}{l}4 \\
7\end{array}$ & 4,7 & 5,0 & 4,7 & - & - & - & 4,8 & $\begin{array}{l}\text { San } \\
\text { gat } \\
\text { Baik }\end{array}$ \\
\hline $\begin{array}{l}\text { Uji Coba } \\
\text { Kelompo } \\
\text { k kecil }\end{array}$ & - & - & - & - & & - & - & - & - & 4,5 & 4,5 & 4,6 & 4,5 & $\begin{array}{l}\text { San } \\
\text { gat } \\
\text { Baik }\end{array}$ \\
\hline
\end{tabular}




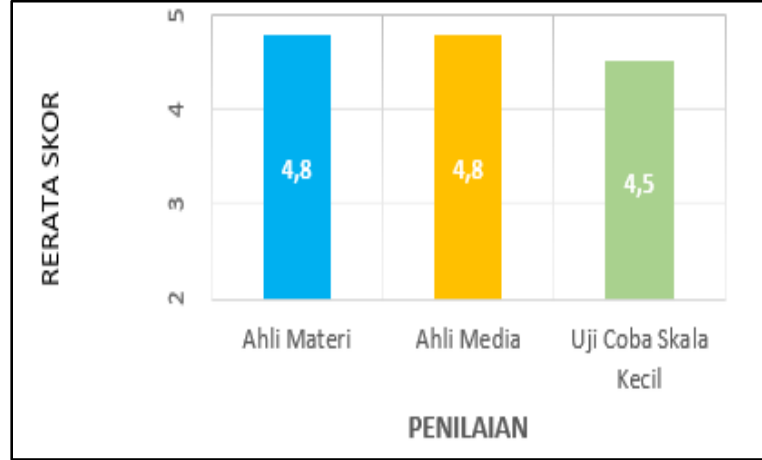

Gambar 3. Data Penilaian Media Pembelajaran

Berdasarkan tabel 2 dan gambar 3 tersebut, validasi oleh ahli materi terhadap media pembelajaran interaktif berbasis android hasil pengembangan diperoleh rerata skor sebesar 4,8 , dengan demikian media pembelajaran hasil pengembangan dapat dikategorikan "Sangat Baik". Penilaian yang dilakukan oleh ahli materi ini ditinjau dari 4 aspek, yaitu aspek kelayakan isi, kelayakan kebahasaan, kelayakan penyajian, dan kelayakan penyajian yang semuanya memperoleh skor pada rentang $4,01<x \leq 5,00$ yang berada dalam kategori "Sangat Baik". Hasil skor rata-rata nilai ahli materi sudah mencapai kategori sangat baik karena media yang dikembangkan sudah mencantumkan kompetensi dan tujuan pembelajaran yang jelas, pemberian petunjuk penggunaan yang mudah dipahami, dan pengemasan materi yang ringkas sehingga lebih menarik perhatian dan minat siswa dalam belajar. Pernyataan ini sejalan dengan Sanjaya (2021) menyatakan bahwa dalam penyusuan suatu media pembelajaran harus dapat menarik minat siswa dan valid atau sahih. Sutikno (2009) menyebutkan bahwa dalam pembuatan media pembelajaran harus memperhatikan ketepatan tujuan pembelajaran dan dukungan terhadap isi materi pelajaran yang sifatnya fakta, prinsip, dan konsep agar lebih mudah dipahami oleh siswa. Saran yang diperoleh pada tahap validasi materi yaitu yaitu pada bagian latihan soal. Saran dari ahli materi yaitu sebaiknya dalam latihan soal siswa tidak perlu diberi batas waktu dalam mengerjakan, karena ini akan berdampak pada konsentrasi siswa dalam berfikir untuk menentukan jawaban yang benar sehingga akan membuat siswa terburu-buru dalam mengerjakan yang akhirnya membuat jawaban siswa salah. Hal ini sejalan dengan yang diungkapkan oleh Akhmad, et. al, (2016) yang mengatakan bahwa murid memerlukan ketenangan dan konsentrasi untuk berfikir sebelum melakukan sesuatu seperti menulis, berbicara, maupun melakukan tindakan. Dari saran ini peneliti memperbaiki media dengan cara menghilangkan hitungan waktu mundur pada saat murid mengerjakan soal, sehingga murid menjadi lebih tenang dalam mengerjakan soal.

Hasil validasi atau penilaian dilakukan oleh ahli media terhadap media pembelajaran interaktif hasil pengembangan diperoleh rerata skor sebesar 4,8, dengan demikian media pembelajaran hasil pengembangan dapat dikategorikan "Sangat Baik". Penilaian yang dilakukan oleh ahli media ini ditinjau dari 5 aspek, yaitu aspek kelayakan tampilan, rekayasa perangkat lunak, antarmuka, kemudahan, dan kompabilitas yang semuanya memperoleh skor dengan rentang $4,01<\mathrm{x} \leq$ 5,00 yang berada dalam kategori "Sangat Baik". Hasil skor rata-rata nilai oleh ahli media sudah mencapai kategori sangat baik karena media yang dikembangkan sudah dilengkapi dengan penyisipan multimedia yang beragam sehingga tidak membosankan ketika digunakan serta penggunaan menu dan ikon dari aplikasi yang mudah dipahami sehingga tidak membingungkan ketika digunakan. Hal ini sesuai dengan pernyataan Rohinah (2016) yang menyatakan bahwa kemudahan dalam mengakses aplikasi membuat siswa menjadi lebih tertarik dalam mempelajari materi yang disediakan. Pada tahap validasi media diperoleh saran berupa suara latar (backsound) yang terlalu keras, sehingga mengganggu suara narasi pembawa materi, usahakan suara latar tetap ada, akan tetapi 
tidak mengganggu suara pembawa narasi, karena jika suara latar dimatikan suasana belajar kurang menyenangkan. Saran ini sejalan dengan yang diungkapkan oleh Novitasari (2016) yang menyebutkan bahwa penggabungan dari gambar, animasi, dan suara yang menarik akan menghilangkan rasa bosan yang dialami murid karena pembelajaran menjadi tidak monoton dan membuat murid menjadi tertarik untuk mempelajari materi yang disajikan. Hal ini juga sesuai dengan teori kognitif tentang pembelajaran dengan memanfaatkan multimedia yang memiliki potensi untuk menghasilkan pemahaman dan pembelajaran yang lebih bermakna dan mendalam dari pada presentasi yang ditampilkan hanya dalam satu format, misalnya hanya dalam bentuk gambar atau kata-kata saja. Untuk saran ini perbaikan media yang peneliti lakukan adalah menurunkan (decrease) suara latar (backsound) dengan tetap mempertahankan fitur ini, sehingga tidak mengganggu suara utama pembawa materi dan tetap membuat suasana belajar menjadi menyenangkan.

$$
\text { Setelah direvisi berdasarkan }
$$
masukan dari ahli materi dan ahli media, langkah selanjutnya media pembelajaran hasil pengembangan diujicobakan kepada 10 siswa kelas VI SD No. 6 Pecatu. Berdasarkan tabel 3 dan gambar 2 hasil dari penilaian uji coba kelompok kecil terhadap media pembelajaran hasil pengambangan diperoleh rerata skor keseluruhan sebesar 4,5 , dengan demikian media pembelajaran masuk dalam kategori "Sangat Baik". Penilaian yang dilakukan pada uji coba kelompok kecil ini ditinjau dari 3 aspek, yaitu aspek kualitas media, penyajian materi, dan manfaat yang semuanya memperoleh skor pada rentang 4,01<x 5 5,00 yang berada dalam kategori "Sangat Baik". Dengan begitu, dapat disimpulkan bahwa media pembelajaran interaktif berbasis android dikatakan praktis. Pada tahap uji coba kelompok kecil ini tidak terdapat saran perbaikan, sehingga media pembelajaran interaktif berbasis android ini tidak perlu dilakukan revisi lagi dan layak digunakan di sekolah. Beberapa catatan berupa komentar yang diperoleh pada uji coba kelompok kecil diantaranya adalah murid merasa senang karena belajar menjadi tidak membosankan karena terdapat musik yang enak didengar dan gambar yang bagus, murid ingin mempelajari materi lain dengan menggunakan media berbasis android, murid merasa terbantu dalam memahami materi karena terdapat gambar dan ilustrasi, dan murid merasakan seperti bermain game padahal sedang belajar. Berdasarkan beberapa komentar yang diberikan murid pada uji coba kelompok kecil dapat disintesis bahwa dengan kehadiran aplikasi pembelajaran berbasis android ini, yang mampu menampung dan mengkombinasikan berbagai jenis media yang berupa gambar, suara, animasi dan video, membuat murid semangat dan senang serta termotivasi dalam belajar karena dapat merasakan belajar sambil bermain sehingga murid dapat lebih menguasai materi yang diberikan. Hal ini sejalan dengan apa yang disampaikan oleh Widiastika, et. al. (2021) yang menyatakan bahwa kehadiran media berbasis android dapat meningkatkan kualitas pembelajaran dan memikat perhatian murid yang pada akhirnya dapat meningkatkan motivasi murid dalam belajar sehingga mampu memahami materi pembelajaran menjadi lebih baik dan dapat mencapai tujuan pembelajaran. Sedangkan Susilana (dalam Widiastika, et. al. 2021) menyatakan bahwa murid akan cenderung lebih suka pada halhal menarik seperti visualisasi gambar, warna yang memikat, animasi yang menarik sehingga mampu meningkatkan pemahaman dan hasil dalam belajar. Kegiatan validasi untuk pengujian kepraktisan media pembelajaran interaktif berbasis android ini baru dilakukan pada tahap uji coba kelompok kecil, sehingga dibutuhkan penelitian selanjutnya dengan melibatkan responden yang lebih besar dengan tujuan untuk menguji efektifitas media pembelajaran hasil pengembangan, 
sehingga media pembelajaran interaktif hasil pengembangan dapat lebih disempurnakan lagi dan menjadi layak digunakan dalam kegiatan pembelajaran di sekolah.

Beberapa penelitian dengan topik pengembangan media pembelajaran dengan berbasis android pernah dilakukan oleh peneliti-peneliti lainnya. Amajida (2020) hasil penelitiannya mengungkap bahwa hasil validasi para ahli materi berada pada rata-rata 4 dengan kategori baik, untuk ahli media mendapatkan rata-rata 4,5 dengan kategori "Sangat Baik". Sehingga berdasarkan hasil akumulasi ahli media dan materi diperoleh rata-rata 4,25 yang artinya valid, dengan kategori layak. Artinya media yang dikembangkan layak untuk digunakan. Pada menu latihan pada aplikasi ini, terdapat timer yang membatasi dalam waktu mengerjakan, sehingga user menjadi terburu-buru ketika mengerjakan. Kuswanto (2019) dalam penelitiannya menegaskan bahwa penggunaan media pembelajaran dengan berbasis android layak digunakan sebagai media pembelajaran yang praktis, ekonomis, dan sesuai dengan fasilitas yang dimiliki siswa. Kendala yang ditemukan dalam penelitian ini adalah dibutuhkan android dengan spesifikasi yang tinggi dengan RAM 1 GB dan Memori internal 4 GB agar media pembelajaran dapat berjalan dengan lancar.

Berdasarkan beberapa hasil penelitian sebelumnya yang dilakukan dengan menggunakan berbagai metode yang berbeda, diperoleh hasil akhir yang tetap sama, demikian juga dengan hasil penelitian ini dapat dikatakan sesuai dan sama dengan penelitian-penelitian yang diungkapkan diatas. Berpijak dari hasil tersebut, dapat disintesiskan bahwa penggunaan media pembelajaran berbasis android diyakini dapat meningkatkan kemandirian, minat dan motivasi murid dalam belajar yang pada akhirnya akan dapat meningkatkan hasil belajar murid yang dibuktikan dengan respon yang sangat baik dan positif dari murid dan guru sebagai praktisi.

Pada hasil penelitian pengembangan ini, ditemukan bebarapa kelebihan dan kekurangan terkait tahap-tahap pengembangan dan produk media pembelajaran yang interaktif yang diperoleh. Kelebihan yang dapat peneliti temukan pada penelitian ini diantaranya adalah: (1) aplikasi media pembelajaran interaktif hasil pengembangan hanya membutuhkan perangkat android dengan RAM 500 MB dan memori intenal $1 \mathrm{~GB}$ untuk dapat menjalankan aplikasi, sehingga pada saat dilakukan uji coba kelompok kecil semua siswa dapat menjalankan aplikasi media pembelajaran dengan lancar; (2) Media pembelajaran interaktif berbasis android hasil pengembangan dikemas dengan menarik dan singkat dengan memperhatikan komposisi media yang beragam (video, audio, animasi, gambar, teks), sehingga membuat siswa tertarik dan senang ketika menjalankan aplikasi, hal ini dibuktikan dari komentar yang siswa berikan ketika dilakukan uji coba kelompok kecil yang menunjukkan hal tersebut; (3) Pada soal latihan dan game tidak diberikan timer atau batas untuk mengerjakan, sehingga siswa menjadi tidak terburu-buru dalam mengerjakan; (4) Pada soal latihan tidak diberikan menu back dan home, dengan tujuan supaya siswa menyelesaikan rangkaian soal dari awal sampai akhir. Hal ini dimasudkan untuk menanamkan pendidikan karakter pada siswa supaya menjadi lebih fokus, disiplin, berkomitmen diri, dan bertanggung jawab. Hasil penelitian ini akan memberi wawasan dan pemahaman kepada guru dan mahasiswa program studi Pendidikan Dasar bahwa penggunaan teknologi yang sesuai dengan perkembangan jaman, akan berdampak positif dalam bidang pendidikan.

Kekurangan yang ditemukan pada penelitian ini diantaranya: (1) Pengembangan media pembelajaran ini baru dilaksanakan sampai tahap development (pengembangan) sehingga 
hasil dari uji kepraktisan tidak maksimal diperoleh, maka diperlukan tindakan selanjutnya berupa implementasi yang lebih luas sehingga media pembelajaran interaktif hasil pengembangan dapat teruji dengan baik kepraktisan maupun efektivitasnya dan dapat dilakukan penyempurnaan produk yang pada akhirnya layak digunakan dalam kegiatan belajar mengajar; (2) Materi yang terkandung dalam media pembelajaran interaktif sebatas pengertian pengenalan jenis-jenis perkembangbiakan hewan, sehingga perlu dikembangkan lagi dengan menambahkan materi yang lebih luas terkait perkembangbiakan hewan; (3) Pada tampilan kuis dan latihan soal dalam media pembelajaran interaktif ini hanya sebatas drag and drop dan pilihan ganda, serta respon yang diberikan ketika siswa menjawab soal baru sebatas konfirmasi jika jawaban siswa sudah benar atau salah.

\section{PENUTUP}

Berdasarkan hasil penelitian dan pembahasan, dapat disintesiskan bahwa penelitian ini menghasilkan media pembelajaran interaktif yang dapat digunakan melalui smartphone bersistem android pada mata pelajaran IPA dengan pokok bahasan perkembangbiakan hewan yang dikemas dalam bentuk aplikasi (.apk) yang dapat dioperasikan secara offline (stand alone). Hasil validasi media pembelajaran interaktif pada mata pelajaran IPA dengan topik perkembangbiakan hewan memiliki kategori Sangat Baik, hal ini didasarkan pada hasil analisis validasi ahli materi yang memperoleh rerata skor 4,8, ahli media dengan rerata skor 4,8 , dan uji coba kelompok kecil sebesar 4,5. Hal ini membuktikan bahwa produk pengembangan media pembelajaran berbasis android layak dan praktis.

Berdasarkan hasil penelitian, terdapat beberapa saran yang dapat diajukan yaitu: bagi murid, sebaiknya menggunakan ponsel pintar yang dimilikinya untuk kegiatan positif, misalnya belajar menggunakan aplikasi android hasil pengembangan sehingga dapat lebih mudah memahami materi khususnya pada mata pelajaran IPA pada pokok bahasan perkembangbiakan hewan. Bagi guru, hendaknya dapat melakukan inovasi dalam mengembangkan dan menggunakan media pembelajaran berbasis teknologi, karena pembelajaran yang memanfaatkan teknologi terkini tentu dapat meningkatkan minat dan antusias murid yang pada akhirnya membuat murid menjadi lebih aktif dalam belajar. Untuk peneliti selanjutnya, terdapat tiga saran yang dapat peneliti berikan yaitu: (1) Mengingat penelitian pengembangan ini baru dilakukan sampai pada tahap uji coba kelompok kecil, maka dibutuhkan penelitian selanjutnya untuk menguji tingkat efektifitas media pembelajaran hasil pengembangan, sehingga media pembelajaran hasil pengembangan dapat lebih disempurnakan lagi. (2) Hendaknya peneliti selanjutnya mengembangkan media dengan menambahkan materi yang lebih luas untuk menunjukkan tahap-tahap perkembangbiakan hewan dengan lebih interaktif.

\section{DAFTAR PUSTAKA}

Akhmad, F., \& Fahruddin, I. 2016. Korelasi Antara Self Confidence Dan Personality Dengan Hasil Belajar Matematika. Disampaikan pada Semnas UNY. Universitas Negeri Yogyakarta.

Desriana, D., Amsal, A., \& Husita, D. 2018. Perbandingan hasil belajar siswa menggunakan media pembelajaran berbasis lingkungan dengan media internet dalam pembelajaran asam basa di MAN Indrapuri. Jurnal IPA \& Pembelajaran IPA, 2(1), 50-55.

Fauzi, A. E. N. 2020. Pelatihan Guru dalam Menghadapi Era Globalisasi. Jurusan Teknologi Pendidikan, Fakultas IImu Pendidikan, Universitas Negeri Malang

Handoyono, N. A., \& Mahmud, A. 2020. Pengembangan Media Pembelajaran 
Berbasis Android pada Pembelajaran Electronic Fuel Injection. Jurnal Inovasi Vokasional dan Teknologi, 20(2), 107-116.

Hermawan, I. 2019. Metodologi Penelitian Pendidikan (Kualitatif, Kuantitatif dan Mixed Method). Jakarta: Hidayatul Quran.

Ichsan, I. Z., Dewi, A. K., Hermawati, F. M., \& Iriani, E. 2018. Pembelajaran IPA dan lingkungan: analisis kebutuhan media pembelajaran pada $S D$, SMP, SMA di Tambun Selatan, Bekasi. JIPVA (Jurnal Pendidikan IPA Veteran), 2(2), 131-140.

Koyan, I Wayan. 2012. Statistik Pendidikan, Teknik Analisis Data Kuantitatif. Singaraja: Universitas Pendidikan Ganesha Press.

Kuswanto, J. 2018. Media Pembelajaran Berbasis Android Pada Mata Pelajaran Sistem Operasi Jaringan Kelas XI. Jurnal Media Infotama, 14(1).

Lubis, I. R., \& Ikhsan, J. 2016. Pengembangan media pembelajaran kimia berbasis android untuk meningkatkan motivasi belajar dan prestasi kognitif peserta didik SMA. Jurnal Inovasi Pendidikan IPA, 1(2), 191-201.

Mulyatiningsih, E. 2014. Metode Penelitian Terapan Bidang Pendidikan. Bandung: CV Alfabeta.

Novitasari, D. 2016. Pengaruh penggunaan multimedia interaktif terhadap kemampuan pemahaman konsep matematis siswa. FIBONACCI: Jurnal Pendidikan Matematika Dan Matematika, 2(2), 8-18.

Nurseto, Tejo. 2019. Membuat Media Pembelajaran yang Baik. Universitas Negeri Yogyakarta. Jurnal Ekonomi \& Pendidikan, Volume 8, Nomor 1.
Nurwahyuningtyas, I, 2017. Pengembangan Media Pembelajaran Mobile Learning Berbasis Android Mata Pelajaran Ipa Untuk Siswa Smp. Refleksi Edukatika: Jurnal IImiah Kependidikan, 8(1).

Perwita, D. P., Kandika, P. S., \& Oktrisma, Y. 2019. Analisis Model Pengembangan Bahan Ajar. Makalah disajikan tanggal 4 November 2019 pada Program Pasca Sarjana Universitas Negeri Padang.

Purbasari R.J, Kahfi M.S, dan Yunus M. 2013. Pengembangan Aplikasi Android Media Pembelajaran Matematika pada Materi Dimensi Tiga untuk Siswa SMA Kleas $X$. Artikel Olmiah pada Jurnal Online UM

Rahayu, D., \& Handayani, D. V. 2020. Pengembangan Media Pembelajaran Interaktif Berbasis Android Menggunakan Ispring Dan Apk Builder Untuk Pembelajaran Matematika Kelas $X$ Materi Proyeksi Vektor. Mathline: Jurnal Matematika dan Pendidikan Matematika, 5(1), 1225.

Rohinah. 2016. "Pengembangan Aplikasi Bahan Ajar Pendidikan Agama Islam Berbasis Android Di Sekolah Menengah Atas." Al Athfal: Jurnal Pendidikan Anak.

Sanjaya, Wina. 2012. Media Komunikasi Pembelajaran. Jakarta: PT Kharisma Putra Utama.

Sari, R. R., Febrini, D., \& Walid, A. 2021. Tantangan Guru Pai Dalam Menghadapi Era Perubahan Globalisasi Teknologi Industri 4.0 di SMA Negeri 01 Bengkulu Tengah. GHAITSA: Islamic Education Journal, 2(1), 26-34.

Sumiharsono, R., \& Hasanah, $H$. 2017. Media Pembelajaran: Buku Bacaan Wajib Dosen, Guru dan Calon Pendidik. Pustaka Abadi. 
Diterima : 31-08-2021 | Disetujui : 20-09-2021| Diterbitkan : 28-09-2021

Suryanti, S. 2018. Pengembangan Media Game Edukatif "Lecy Explore" Berbasis Android Untuk Siswa Kelas Iv Sd Materi Siklus Hidup Hewan Dan Upaya Pelestariannya.

Sutarti, Tatik. Edi Irawan. 2017. Kiat Sukses Meraih Hibah Penelitian Pengembangan. Sleman: Deepublish.

Sutikno, M. Sobry. 2009. Belajar Dan Pembelajaran. Jakarta: PT Elex Media Komputindo.

Tegeh, I. M., Jampel, I. N., \& Pudjawan, K. 2014. Model penelitian pengembangan. Yogyakarta: Graha IImu.

Umi, Christiana. 2016. Cepat Kuasai IPA $S D$. Jakarta: Grasindo.

Verawati, V., \& Comalasari, E. 2019. Pemanfaatan Android Dalam Dunia Pendidikan. In prosiding seminar nasional program pascasarjana universitas pgri palembang pada bulan Juli 2019.

Widiastika, Milda Asti. Nana Hendracipta.A. Syachruroji. 2021. Pengembangan Media Pembelajaran Mobile Learning Berbasis Android pada Konsep Sistem Peredaran Darah di Sekolah Dasar. Jurnal: Basic Edu, Volume 5 Nomor 1.

Yulia Siska. 2018. Pembelajaran IPS di SD/MI. Yogyakarta: GarudhaWaca. 